JIEB (ISSN : 2442-4560) available online at : ejournal.stiepancasetia.ac.id

\title{
PENGARUH KEANDALAN DAN PROSEDUR PELAYANAN TERHADAP KEPUASAN MASYARAKAT PADA KANTOR URUSAN AGAMA LIANG ANGGANG KOTA BANJARBARU
}

\author{
Fahlin Najmi \\ Kantor Urusan Agama Liang Anggang Kota Banjarbaru \\ Jl. Pembangunan, Landasan Ulin Tengah, Liang Anggang, Banjarbaru \\ e-mail :fahminajmi@gmail.com
}

\begin{abstract}
Reliable service and an accurate service procedure is a must for government agency that serve directly to society needs, including Banjarbaru City Liang Anggang Religious Affairs Office. This study aims to determine the effects of reliability and procedures on public satisfaction on Banjarbaru City Liang Anggang Religious Affairs Office. The method of this research is quantitative. The amounts of population were 50, while the samples were 50 . The data analysis techniques were multiple linear regressions. The results showed that the variables of reliability and procedures had partial and simultaneous influence on public satisfaction on Banjarbaru City Liang Anggang Religious Affairs Office.
\end{abstract}

Keywords: reliability, procedure, public satisfaction, Banjarbaru City Liang Anggang Religious Affairs Office

\begin{abstract}
Abstrak: Pelayanan yang andal dengan dilengkapi prosedur pelayanan yang akurat harus dimiliki oleh instansi pemerintah yang memberikan pelayanan langsung kepada masyarakat, termasuk Kantor Urusan Agama Liang Anggang Kota Banjarbaru. Penelitian ini bertujuan untuk mengetahui seberapa besar pengaruh keandalan dan prosedur pelayanan terhadap kepuasan masyarakat pada Kantor Urusan Agama Liang Anggang Kota Banjarbaru. Metode yang digunakan dalam penelitian ini adalah metode kuantitatif. Jumlah populasi sebanyak 50 orang dan sampel sebanyak 50 orang. Teknik analisis data dengan menggunakan regresi linear berganda. Hasil penelitian ini menunjukkan bahwa variabel keandalan dan prosedur pelayanan secara parsial dan simultan berpengaruh terhadap kepuasan masyarakat pada Kantor Urusan Agama Liang Anggang Kota Banjarbaru.
\end{abstract}

Kata Kunci: keandalan, prosedur pelayanan, kepuasan masyarakat, Kantor Urusan Agama Liang Anggang Kota Banjarbaru

\section{Latar Belakang}

Pelayanan publik oleh pemerintah kepada masyarakat merupakan perwujudan fungsi aparatur negara sebagai abdi masyarakat. Oleh karena itu, fasilitas publik harus lebih didekatkan pada masyarakat sehingga mudah dijangkau dengan kualitas pelayanan yang lebih baik, agar dapat memberikan kepuasan kepada masyarakat.

Era reformasi identik dengan hak asasi dan masyarakat semakin kritis serta selalu merasa kurang puas atas pelayanan pemerintah saat ini. Untuk menjawab tantangan ini, pemerintah dalam hal ini Kementerian Aga- ma Republik Indonesia melalui Kantor Urusan Agama (KUA) Liang Anggang Kota Banjarbaru berupaya menjalankan salah satu misinya, yaitu meningkatkan kualitas pelayanan melalui tertib administrasi dalam proses maupun produk pelayanan untuk memberikan kepastian hukum sebagai wujud tanggung jawab pelaksanaan tugas.

Pelayanan publik atau pelayanan umum yang diselenggarakan oleh organisasi publik dapat dibedakan menjadi sebagai berikut ini.

1. Yang bersifat primer, adalah semua penyediaan barang/jasa publik yang diselenggarakan oleh pemerintah yang di da- 
lamnya pemerintah merupakan satu-satunya penyelenggara. Pengguna/klien mau tidak mau harus memanfaatkannya. Misalnya adalah pelayanan di kantor imigrasi, KUA dan pelayanan perizinan.

2. Yang bersifat sekunder, adalah segala bentuk penyediaan barang/jasa publik yang diselenggarakan oleh pemerintah. Pengguna/klien tidak harus mempergunakannya karena adanya beberapa penyelenggara pelayanan.

Ada lima karakteristik yang dapat dipakai untuk membedakan ketiga jenis penyelenggaraan pelayanan publik tersebut, yaitu sebagai berikut ini.

1. Adaptabilitas layanan, berarti derajat perubahan layanan sesuai dengan tuntutan perubahan yang diminta oleh pengguna.

2. Posisi tawar pengguna/klien, di mana semakin tinggi posisi tawar pengguna/klien, maka akan semakin tinggi pula peluang pengguna untuk meminta pelayanan yang lebih baik.

3. Tipe pasar, menggambarkan jumlah penyelenggara pelayanan yang ada dan hubungannya dengan pengguna/klien.

4. Locus control, menjelaskan siapa yang memegang kontrol atas transaksi. Apakah pengguna atau penyelenggara pelayanan.

Kualitas tidak lagi hanya bermakna kesesuaian dengan spesifikasi tertentu, tetapi kualitas tersebut ditentukan masyarakat. Oleh karena itu, segala aktivitas organisasi harus dikoordinasikan untuk memuaskan masyarakat. Kualitas memberikan suatu dorongan kepada masyarakat untuk menjalin ikatan yang kuat dengan organisasi.

Dalam jangka panjang ikatan seperti ini memungkinkan organisasi memahami dengan seksama harapan masyarakat serta kebutuhan mereka. Dengan demikian, organisasi tersebut dapat meningkatkan kepuasan masyarakat dengan cara, organisasi memaksimumkan pengalaman masyarakat yang menyenangkan dan meminimumkan atau meniadakan pengalaman masyarakat yang kurang menyenangkan. Pada gilirannya kepuasan masyarakat dapat menciptakan kesetiaan atau loyalitas kepada organisasi yang memberikan kualitas yang memuaskan.
KUA Liang Anggang Kota Banjarbaru merupakan tempat di mana pegawai bekerja untuk melayani segala kebutuhan yang diperlukan masyarakat di wilayahnnya. Alasan penelitian ini dilakukan di KUA Liang Anggang Kota Banjarbaru karena obyek inilah yang paling banyak berinteraksi langsung dengan masyarakat umum.

Penelitian ini berusaha untuk mengungkapkan apakah expectation service masyarakat sudah sama dengan perceived servicenya. Oleh karena itu, permasalahan hanya membatasi untuk mengungkapkan ada atau tidak adanya kesenjangan yang mungkin terjadi antara expectation dan perceived servicenya. Bila ada dimensi quality of service mana yang menyebabkan kesenjangan terbesar.

Dalam penelitian ini dimensi kualitas pelayanan yaitu keandalan (reliability) menjadi permasalahan belakangan ini dibandingkan dimensi kualitas pelayanan lainnya. Oleh karena itu, penulis hanya mengambil dimensi faktor keandalan (reliability) untuk dijadikan variabel penelitian, sejauh mana nantinya keandalan (reliability) akan mempengaruhi kepuasan masyarakat.

Di beberapa kecamatan di Kota Banjarbaru, peningkatan pelayanan publik terus ditingkatkan, salah satunya adalah KUA Liang Anggang Kota Banjarbaru. Kementerian Agama Republik Indonesia telah berupaya meningkatkan kinerja pelayanan publik, pemberian pelayanan kepada masyarakat di KUA Liang Anggang Kota Banjarbaru, terutama mengenai ijin menikah dan pelayanan lainnya, masih sering dikeluhkan karena dirasa sulit, berbelit, panjang, dan lama penyelesaiannya. Melihat kecenderungan tersebut, maka Kementerian Agama Kota Banjarbaru membuat kebijakan pelayanan yang bersifat "satu pintu". Unit ini merupakan sarana pelayanan umum yang memberikan beberapa jenis pelayanan umum kepada masyarakat, yang diselenggarakan secara terpadu di KUA Liang Anggang Kota Banjarbaru.

KUA Liang Anggang Kota Banjarbaru memiliki tugas untuk mengadakan pelayanan umum di bidang perijinan dan rekomendasi bidang agama, seperti pembuatan surat keterangan nikah, waris, dan lain sebagainya, serta mengkoordinir kelurahan yang berada di bawah lingkup KUA Liang Anggang Kota 
Banjarbaru. Dengan kompleknya permasalahan yang dihadapi menjadi satu keharusan bagi setiap kecamatan untuk meberikan pelayanan kepada masyarakat dengan sesuai prosedur yang berlaku merupakan hal yang terpenting. Oleh karena itu, diharapkan mampu untuk selalu konsisten pada perannya, terutama kuantitas dan kualitas pelayanan dalam upaya memuaskan kebutuhan dan keinginan masyarakat.

Penelitian ini diharapkan akan lebih menumbuhkan kesadaran akan pentingnya keandalan dan prosedur pelayanan untuk memberikan yang terbaik terhadap masyarakat, dan dasar bagi pengembangan kualitas pelayanan di masa yang akan datang, karena kepuasan masyarakat tidak pernah berhenti.

\section{Kajian Literatur}

Abidin (2010), memberikan pengertian keandalan adalah salah satu dimensi dari pelayanan berkualitas. Pelayanan berkualitas merupakan upaya yang dilakukan oleh perusahaan untuk memenuhi harapan pelanggannya. Pelayanan yang berkualitas lebih menekankan aspek kepuasan konsumen yang diberikan oleh perusahaan yang menawarkan jasa. Keberhasilan suatu perusahaan yang bergerak di sektor jasa tergantung pelayanan yang ditawarkan.

Lupiyoadi (2011) menyatakan ada lima dimensi pelayanan, yaitu tangibles (bukti fisik), reliability (keandalan), responsiveness (ketanggapan), assurance (jaminan) dan empathy. Reliability atau keandalan yaitu kemampuan perusahaan untuk memberikan pelayanan sesuai yang dijanjikan secara akurat dan terpercaya. Kinerja harus sesuai dengan harapan pelanggan yang berarti ketepatan waktu, pelayanan yang sama untuk semua pelanggan tanpa kesalahan, sikap yang simpatik, dan dengan akurasi yang tinggi.

Ariani (2012) menyatakan bahwa reliability adalah konsistensi kerja pemberi jasa dan kemampuan pemberi jasa dalam memenuhi janji para penerima jasa. Abidin (2010) bahwa reliability adalah kemampuan untuk memberikan pelayanan yang dijanjikan dengan tepat (accurately) dan kemampuan untuk dipercaya (dependably), terutama memberikan jasa secara tepat waktu (ontime), dengan cara yang sama sesuai dengan jadwal yang telah dijanjikan dan tanpa melakukan kesalahan setiap kali. Adapun atributatribut yang berada dalam dimensi ini antara lain adalah:

1. memberikan pelayanan sesuai janji;

2. pertanggung jawaban tentang penanganan konsumen akan masalah pelayanan;

3. memberi pelayanan yang baik saat kesan pertama kepada konsumen;

4. memberikan pelayanan tepat waktu; dan

5. memberikan informasi kepada konsumen tentang kapan pelayanan yang dijanjikan akan direalisasikan.

Keandalan adalah kemampuan untuk menyediakan pelayanan yang terpercaya dan akurat. Kinerja harus sesuai dengan harapan pelanggan tanpa kesalahan. Ada pula yang mendefinisikan sebagai kemampuan untuk melaksanakan jasa yang dijanjikan dengan terpercaya dan akurat. Hal ini berarti tingkat keandalan di mata pelanggan, meliputi kemampuan memberikan layanan yang dijanjikan dengan segera, akurat, dan memuaskan, yang meliputi catatan transaksi yang lengkap, kredibilitas/bonafiditas/citra perusahaan dan daya tarik keunggulan kualitas pelayanan

Menurut Zahruli (2012) yaitu kemampuan memberikan pelayanan yang sesuai secara akurat dan terpercaya, sikap simpatik dan dengan akurasi yang tinggi kepada para pasien. Keandalan diukur dengan tindakan pelayanan yang akurat oleh pegawai, profesionalisme dalam menangani keluhan masyarakat oleh para pegawai, melayani dengan baik dan ramah saat memberikan pelayanan dengan tepat dan benar sesuai dengan prosedur yang ditetapkan dalam memberikan pelayanan selalu sesuai dengan jadwal yang telah ditetapkan.

Keandalan mempunyai arti kemampuan perusahaan untuk memberikan layanan yang akurat sejak pertama kali tanpa membuat kesalahan apapun dan menyampaikan jasanya sesuai dengan waktu tertentu. Keandalan adalah kemungkinan produk untuk tidak berfungsi pada periode waktu tertentu. Intinya, reliabilitas (kepercayaan) adalah saat seluruh Informan percaya bahwa pelayanan di tempat pelayanan tertentu bagi mereka sangat memuaskan dan seperti yang diharapkan. 
Kepmen PAN No. 63/Kep/M.Pan/7/ 2003 tentang Pedoman Umum Penyelenggaraan Pelayanan Publik, menegaskan bahwa dalam rangka upaya meningkatkan kualitas pelayanan publik. Setiap penyelenggaraan pelayanan publik harus memiliki standar pelayanan dan dipublikasikan sebagai jaminan adanya kepastian bagi penerima pelayanan. Standar pelayanan merupakan ukuran yang diberlakukan dalam penyelenggaraan pelayanan publik yang wajib ditaati oleh pemberi dan atau penerima pelayanan. Standar pelayanan sekurang-kurangnya memuat, yaitu prosedur pelayanan, waktu penyelesaian, biaya pelayanan, produk pelayanan, sarana dan prasarana, serta kompetensi petugas pemberi pelayanan. Mengacu kepada Kepmen PAN No. 63/Kep/M.Pan/7/2003, juga ditegaskan bahwa sebagai landasan penyusunan standar pelayanan, harus disusun petunjuk pelaksanaan publik, yang sekurang-kurangnya harus memuat, yaitu landasan hukum pelayanan publik, maksud dan tujuan pelayanan publik, sistem dan prosedur pelayanan publik, persyaratan pelayanan publik, biaya pelayan publik, waktu penyelesaian, hak dan kewajiban, dan pejabat penerima pengaduan pelayanan publik.

Mengenai prosedur pelayanan menurut Kepmen PAN Nomor 63/Kep/M.Pan/7/2003, bahwa dalam sistem dan prosedur pelayanan publik sekurang-kurangnya harus memuat: (1) tata cara pengajuan permohonan pelayanan, (2) tata cara penanganan pelayanan, (3) tata cara penyampaian hasil pelayanan, dan (4) tata cara penyampaian pengaduan pelayanan. Penjelasan mengenai empat tata cara yang dimaksud dalam Kepmen PAN No. 63/ Kep/M.Pan/7/2003 tersebut dapat diketahui dengan memahami pengertian prosedur pelayanan itu sendiri. Adapun pengertian prosedur pelayanan tersebut, menurut Kepmen PAN No. 26 tahun 2004 tentang Petunjuk Teknis Transparansi dan Akuntabilitas dalam Penyelenggaraan Pelayanan Publik, menjelaskan bahwa Prosedur pelayanan adalah rangkaian proses atau tata kerja yang berkaitan satu sama lain, sehingga menunjukkan adanya tahapan secara jelas dan pasti serta cara-cara yang harus ditempuh dalam rangka penyelesaian sesuatu pelayanan. Penjelasan Kepmen PAN No. 26 tahun 2004 mengenai prosedur pelayanan tersebut menunjukkan adanya langkah-langkah atau cara-cara sebagai pedoman yang harus dilaksanakan pada setiap tahapan dalam serangkaian proses penyelesaian pelayanan publik.

Berdasarkan pengertian prosedur pelayanan tersebut diatas, maka dapat dijelaskan bahwa empat tata cara yang dimaksud adalah sebagai berikut ini.

1. Tata cara pengajuan permohonan pelayanan, ialah tahapan-tahapan yang jelas dan pasti serta cara-cara yang harus dilaksanakan dalam rangka mengajukan suatu permohonan pelayanan agar permohonan yang diajukan tersebut dapat dilayani atau diproses ke tahap berikutnya. Pada tahap ini biasanya memuat tahap-tahap dan cara-cara yang harus dilaksanakan dan dipenuhi oleh seorang pemohon yang mengajukan permohonan pelayanan tertentu kepada petugas atau pejabat yang berwenang memberikan pelayanan tersebut.

2. Tata cara penanganan pelayanan, ialah tahapan-tahapan yang jelas dan pasti serta cara-cara yang harus dilaksanakan dalam rangka menindak-lanjuti atau menangani suatu permohonan pelayanan yang diajukan. Pada tahap ini petugas atau pejabat yang berwenang harus menangani dan memproses permohonan pelayanan yang diajukan sesuai dengan tata kerja dan ketentuan yang berlaku.

3. Tata cara penyampaian hasil pelayanan, ialah tahapan-tahapan yang jelas dan pasti serta cara-cara yang harus ditempuh dalam rangka menyampaikan hasil pelayanan yang telah selesai ditangani. Pada tahap ini permohonan pelayanan yang telah ditangani oleh petugas atau pejabat yang berwenang akan disampaikan hasilnya kepada pemohon yang bersangkutan. Pemohon dapat menerima hasil pelayanan dengan memenuhi ketentuan tertentu yang berlaku dan terkait dengan jenis pelayanan yang diajukan.

4. Tata cara penyampaian pengaduan pelayanan, adalah tahapan-tahapan yang jelas dan pasti serta cara-cara yang harus ditempuh untuk dapat menyampaikan pengaduan yang berhubungan dengan masalah pelayanan. Pemohon dapat mengadukan atau mengajukan masalah ketidakpuasan dan 
masalah-masalah lain yang berhubungan dengan proses pelayanan pada setiap tahapannya.

Dengan demikian, dapat disimpulkan bahwa yang dimaksud dengan prosedur pelayanan publik adalah kumpulan dari beberapa perintah yang harus dilaksanakan dalam menyelesaikan pelayanan publik agar sesuai dengan apa yang diharapkan. Agar penyelesaian pelayanan publik sesuai dengan yang diharapkan, maka diperlukan kejelasan dan kepastian pada setiap tahapannya. Tahapan-tahapan dalam penyelesaian pelayanan publik, seperti yang telah disebutkan di atas sekurang-kurang harus memuat kejelasan dan kepastian mengenai tata cara dalam proses penyelenggaraan pelayanan publik. Dalam serangkaian proses penyelenggaraan pelayanan harus memuat sekurang-kurangnya mengenai tata cara-tata cara yang pelayanan mulai dari tahap pengajuan permohonan pelayanan, penanganan pelayanan, penyampaian hasil pelayanan hingga penyampaian pengaduan pelayanan. Dengan adanya kejelasan tersebut baik pemberi pelayanan maupun pemohon pelayanan akan mendapatkan kemudahan, kejelasan dan kepastian dalam rangka proses pelayanan publik.

Berkaitan dengan penerapan prosedur pelayanan, maka agar lebih jelas dalam rangka memahami prosedur pelayanan terlebih dahulu perlu diketahui mengenai pengertian prosedur dan pelayanan.

Menurut Widjaja (2011:83), prosedur adalah sekumpulan bagian yang saling berkaitan misalnya orang, jaringan gudang yang harus dilayani dengan cara yang tertentu oleh sejumlah pabrik dan pada gilirannya akan mengirimkan pelanggan menurut proses tertentu. Menurut Kamaruddin (2011), prosedur pada dasarnya adalah suatu susunan yang teratur dari kegiatan yang berhubungan satu sama lainnya dan prosedur-prosedur yang berkaitan melaksanakan dan memudahkan kegiatan utama dari suatu organisasi. Prosedur menurut Masya (2011) adalah suatu rangkaian tugas-tugas yang saling berhubungan yang merupakan urutan-urutan menurut waktu dan tata cara tertentu untuk melaksanakan suatu pekerjaan yang dilaksanakan berulang-ulang.
Berdasarkan pendapat beberapa ahli di atas maka dapat disimpulkan yang dimaksud dengan prosedur adalah suatu tata cara kerja atau kegiatan untuk menyelesaikan pekerjaan dengan urutan waktu dan memiliki pola kerja yang tetap yang telah ditentukan.

Pelayanan adalah suatu aktivitas atau serangkaian aktivitas yang bersifat tidak kasat mata (tidak dapat diraba) yang terjadi akibat adanya interaksi antara konsumen dengan karyawan atau hal-hal lain yang disediakan oleh perusahaan pemberi pelayanan yang dimaksudkan untuk memecahkan permasalahan konsumen/pelanggan (Ratminto dan Atik, 2011). Simamora (2012) menyatakan bahwa pelayanan adalah setiap kegiatan atau manfaat yang ditawarkan suatu pihak kepada pihak lain, yang pada dasarnya tidak berwujud dan tidak mengakibatkan kepemilikan apapun. Menurut Siagian (2001), pelayanan ialah rasa menyenangkan yang diberikan kepada orang lain disertai kemudahan-kemudahan dan memenuhi segala kebutuhan mereka. Pelayanan merupakan suatu bentuk prosedur yang diberikan dalam upayanya memberikan kesenangan-kesenangan kepada orang lain dalam hal ini kepada pelanggan. Pelayanan mengandung pengertian setiap kegiatan atau manfaat yang diberikan oleh suatu pihak kepada pihak lain yang pada dasarnya tidak berwujud dan tidak pula berakibat kepemilikan sesuatu (Kotler, 2011).

Standar pelayanan publik tersebut merupakan ukuran atau persyaratan baku yang harus dipenuhi dalam penyelenggaraan pelayanan publik. Prosedur pelayanan wajib dimiliki oleh institusi penyelenggara layanan publik untuk menjamin diberikannya pelayanan yang berkualitas oleh penyedia layanan publik sehingga masyarakat penerima layanan merasakan adanya nilai yang tinggi atas pelayanan tersebut. Tanpa adanya prosedur yang jelas, maka akan sangat mungkin terjadi pelayanan yang diberikan jauh dari harapan publik. Dalam keadaan seperti itu, akan timbul kesenjangan harapan (expectation gap) yang tinggi (Mahmudi, 2012).

Mahmudi (2012) menjelaskan hal-hal yang perlu diperhatikan dalam standar prosedur pelayanan public sebagai berikut ini. 
1. Kesederhanaan, yaitu prosedur pelayanan hendaknya mudah dipahami dan tidak berbelit-belit.

2. Kejelasan, yaitu dalam hal teknis dan administratif. Kejelasan ini penting bagi masyarakat untuk menghindari terjadinya penyimpangan yang merugikan masyarakat.

3. Kepastian waktu, yaitu pelaksanaan pelayanan publik dapat diselesaikan dalam kurun waktu yang telah ditentukan.

4. Akurasi produk, yaitu produk pelayanan publik yang diberikan harus akurat, benar, tepat, dan sah.

5. Kelengkapan sarana dan prasarana, yaitu tersedianya sarana dan prasarana kerja, peralatan, dan pendukung lainnya yang memadai termasuk teknologi informasi.

6. Keamanan, yaitu proses dan produk pelayanan publik memberikan rasa aman dan kepatian hukum. Oleh karena itu, tidak boleh terjadi intimidasi atau tekanan kepada masyarakat dalam pelayanan.

7. Kemudahan akses, yaitu tempat dan lokasi serta sarana pelayanan yang memadai, mudah dijangkau oleh masyarakat, dan dapat memanfaatkan teknologi informatika.

8. Kenyamanan, yaitu lingkungan pelayanan harus tertib, teratur, disediakan ruang tunggu yang nyaman, bersih, rapi, lingkungan yang indah dan sehat serta dilengkapi dengan fasilitas pendukung, seperti toilet, tempat parkir, tempat ibadah, dan lain sebagainya.

Standar prosedur pelayanan publik tersebut sangat berguna untuk memberikan arah bertindak bagi institusi penyedia pelayanan publik. Selain itu, masyarakat pengguna jasa diharapkan dapat merasakan kepuasan dalam proses pelaksanaannya.

Pada prinsipnya, definisi kualitas pelayanan berfokus pada upaya pemenuhan kebutuhan dan keinginan pelanggan serta ketepatan penyampaian untuk mengimbangi harapan pelanggan. Menurut Wyckoff (1978), kualitas pelayanan adalah tingkat keunggulan yang diharapkan dan pengendalian atas tingkat keunggulan tersebut untuk memenuhi keinginan pelanggan.

Menurut Parasuraman (dalam Lupiyoadi, 2012), lima faktor dalam menen- tukan kualitas pelayanan adalah seba-gai berikut ini.

1. Keandalan (realibility), yaitu kemampuan perusahaan untuk memberikan pelayanan sesuai dengan yang dijanjikan secara akurat dan terpecaya.

2. Daya tanggap (responsiveness), yaitu kesigapan karyawan untuk bersedia membantu dan memberikan pelayanan yang cepat dan tepat kepada pelanggan dan dengan penyampaian informasi yang jelas.

3. Jaminan (assurance), yaitu pengetahuan koresponden dan kemampuan para karyawan perusahaan untuk menumbuhkan rasa percaya pada pelanggan kepada perusahaan.

4. Empati (emphaty), yaitu perhatian, komunikasi yang baik dan pemahaman atas kebutuhan individu pelanggan.

5. Bukti fisik (tangibles), yaitu kemampuan suatu perusahaan dalam menunjukkan eksistensinya kepada pihak eksternal. Bukti fisik meliputi penampilan fisik seperti gedung, perawatan, desain ruangan dan penampilan karyawan.

Kata satisfaction (kepuasan) berasal dari bahasa latin satis, artinya cukup baik, memadai dan factio, artinya melakukan atau membuat. Secara sederhana kepuasan dapat diartikan sebagai upaya pemenuhan sesuatu atau membuat sesuatu memadai. Menurut Kotler (2011) kepuasan adalah tingkat perasaan seseorang setelah membandingkan yang dia rasakan dibandingkan dengan harapannya.

Menurut Oliver dalam Umar (2011), kepuasan pelanggan dirumuskan sebagai evaluasi purna beli, di mana persepsi terhadap kinerja alternatif produk/jasa yang dipilih memenuhi atau melebihi harapan sebelum pembelian. Apabila persepsi terhadap kinerja tidak dapat memenuhi atau melebihi harapan sebelum pembelian, maka yang terjadi adalah ketidakpuasan.

Kepuasan masyarakat merupakan faktor yang sangat penting dan menentukan keberhasilan suatu badan usaha karena masyarakat adalah konsumen dari produk yang dihasilkannya. Hal ini didukung oleh pernyataan Hoffman dan Beteson (2012), bahwa 
tanpa pelanggan, layanan perusahaan tidak punya alasan untuk ada.

Definisi kepuasan masyarakat menurut Mowen (2011) adalah keseluruhan perilaku mengenai barang atau jasa setelah dimiliki atau digunakan. Oleh karena itu, badan usaha harus dapat memenuhi kebutuhan dan keinginan masyarakat sehingga mencapai kepuasan masyarakat dan lebih jauh lagi ke depannya dapat dicapai kesetiaan masyarakat sebab bila tidak dapat memenuhi kebutuhan dan kepuasan masyarakat sehingga menyebabkan ketidakpuasan masyarakat mengakibatkan kesetiaan masyarakat akan suatu produk menjadi luntur dan beralih ke produk atau layanan yang disediakan oleh badan usaha yang lain.

Untuk mengukur kepuasan masyarakat digunakan atribut yang berisi tentang bagaimana masyarakat menilai suatu produk atau layanan yang ditinjau dari sudut pandang pelanggan. Menurut Alan Dutka (2008), kepuasan masyarakat dapat diukur melalui atribut-atribut pembentuk kepuasan yang terdiri atas :

1. Value to price relationship. Hubungan antara harga yang ditetapkan oleh badan usaha untuk dibayar dengan nilai/manfaat yang diperoleh masyarakat.

2. Product value adalah penilaian dari kualitas produk atau layanan yang dihasilkan suatu badan usaha.

3. Product benefit adalah manfaat yang diperoleh masyarakat dari mengkosumsi produk yang dihasilkan oleh badan usaha.

4. Product feature adalah ciri-ciri atau karakteristik tertentu yang mendukung fungsi dasar dari suatu produk sehingga berbeda dengan produk yang ditawarkan pesaing.

5. Product design adalah proses untuk merancang tampilan dan fungsi produk.

6. Product reliability and consistency adalah kekakuratan dan keandalan produk yang dihasilkan oleh suatu badan usaha.

7. Range of product ar services adalah macam dari produk atau layanan yang ditawarkan oleh suatu badan usaha.

Kemudian attribute related to service meliputi :
1. Guarantee or waranty adalah jaminan atau garansi yang diberikan oleh badan usaha dan diharapkan dapat memuaskan masyarakat.

2. Delivery communication adalah pesan atau informasi yang disampaikan oleh badan usaha kepada masyarakatnya.

3. Complain handling adalah sikap badan usaha dalam menangani keluhan keluhan atau pengaduan.

4. Resolution of problem adalah tanggapan yang di berikan badan usaha dalam membantu memecahkan masalah masyarakat yang berkaitan dengan layanan yang diterimanya.

Selanjutnya attributes related to the purchase meliputi :

1. Courtesy adalah kesopanan, perhatian dan keramahan pegawai

2. Communication adalah kemampuan pegawai dalam melakukan komunikasi dengan masyarakat pelanggan.

3. Ease or convinience of acquisition adalah kemudahan yang diberikan oleh badan usaha untuk mendapatkan produk atau layanan yang ditawarkan.

4. Company reputation adalah baik tidaknya reputasi yang dimiliki oleh badan usaha dalam melayani masyarakat.

5. Company competence adalah baik tidaknya kemampuan badan usaha dalam melayani masyarakat.

Berdasarkan prinsip pelayanan sebagaimana telah ditetapkan dalam Kepmen PAN No. 63/KEP/M.PAN/7/2003, yang kemudian dikembangkan menjadi 14 unsur yang relevan, valid dan reliabel, sebagai unsur minimal yang harus ada untuk dasar pengukuran indeks kepuasan masyarakat adalah sebagai berikut ini.

1. Prosedur pelayanan, yaitu kemudahan tahapan pelayanan yang diberikan kepada masyarakat dilihat dari sisi kesederhanaan alur pelayanan.

2. Persyaratan pelayanan, yaitu persyaratan teknis dan administratif yang diperlukan untuk mendapatkan pelayanan sesuai dengan jenis pelayanannya.

3. Kejelasan petugas pelayanan, yaitu keberadaan dan kepastian petugas yang membe- 
rikan pelayanan (nama, jabatan serta kewenangan dan tanggung jawabnya).

4. Kedisiplinan petugas pelayanan, yaitu kesungguhan petugas dalam memberikan pelayanan terutama terhadap konsistensi waktu kerja sesuai ketentuan yang berlaku.

5. Tanggung jawab petugas pelayanan, yaitu kejelasan wewenang dan tanggung jawab petugas dalam penyelenggaraan dan penyelesaian pelayanan.

6. Kemampuan petugas pelayanan, yaitu tingkat keahlian dan ketrampilan yang dimiliki petugas dalam memberikan/menyelesaikan pelayanan kepada masyarakat.

7. Kecepatan pelayanan, yaitu target waktu pelayanan dapat diselesaikan dalam waktu yang telah ditentukan oleh unit penyelenggara pelayanan.

8. Keadilan mendapatkan pelayanan, yaitu pelaksanaan pelayanan dengan tidak membedakan golongan/status masyarakat yang dilayani.

9. Kesopanan dan keramahan petugas, yaitu sikap dan perilaku petugas dalam memberikan pelayanan kepada masyarakat secara sopan dan ramah serta saling menghargai dan menghormati.

10. Kewajaran biaya pelayanan, yaitu keterjangkauan masyarakat terhadap besarnya biaya yang ditetapkan oleh unit pelayanan.

11. Kepastian biaya pelayanan, yaitu kesesuaian antara biaya yang dibayarkan dengan biaya yang telah ditetapkan.

12. Kepastian jadwal pelayanan, yaitu pelaksanaan waktu pelayanan, sesuai dengan ketentuan yang telah ditetapkan.

13. Kenyamanan lingkungan, yaitu kondisi sarana dan prasarana pelayanan yang bersih, rapi, dan teratur sehingga dapat memberikan rasa nyaman kepada penerima pelayanan.

14. Keamanan pelayanan, yaitu terjaminnya tingkat keamanan lingkungan unit penyelenggara pelayanan ataupun sarana yang digunakan, sehingga masyarakat merasa tenang untuk mendapatkan pelayanan terhadap risiko-risiko yang diakibatkan dari pelaksanaan pelayanan.
Pohan (2012) menyebutkan faktorfaktor yang mempengaruhi keandalan (reliability) meliputi sebagai berikut ini.

1. Ability, yaitu seorang petugas harus memiliki kemampuan teori dan pengalaman lapangan sehingga pada pelaksanaan tugasnya, petugas yang dimaksud mampu menunjukkan prestasi.

2. Performance, yaitu membina dan memelihara kinerja dari petugas dan institusi yang diwakilinya merupakan kewajiban petugas yang handal.

3. Personality, yaitu seorang petugas sangat erat hubungannya dengan rasa tanggung jawab sebagai petugas serta memelihara tugas-tugas di bidang pelayanan yang berkaitan dengan kepuasan pengguna jasa pelayanan yang menjadikan kepribadian yang sangat penting.

4. Credibility, yaitu batu ujian bagi para petugas pelayanan yang berusaha mendukung upaya melayanai, tanpa memiliki rasa ragu dalam menangani masalah yang diberikan.

5. Maturity, yaitu kemampuan mengendalikan kondisi, dalam hal ini kemampuan jiwa yang dewasa dan cukup matang untuk mengendalikan diri orang lain.

Moekijat (2011), menyebutkan hal-hal yang mencakup keandalan (reliability), yaitu keterampilan petugas, kelengkapan sarana, dan ketepatan waktu.

Psikologi industri menyatakan bahwa keterampilan kerja adalah kemampuan seseorang dalam melaksanakan pekerjaannya (As'ad 2012). Jadi, keterampilan kerja dapat diartikan sebagai hasil yang dapat dicapai seseorang menurut ukuran yang berlaku untuk pekerjaan atau tugas yang bersangkutan. Keterampilan kerja antara orang yang satu dengan orang yang lainnya dalam situasi kerja adalah perbedaan karakteristik individual. Disamping itu, orang yang sama dapat membentuk penampilan kerja yang berbeda dalam situasi yang berbeda pula. Dari sinilah dapat disimpulkan bahwa kerja seseorang dipengaruhi oleh faktor situasi (As'ad, 2012).

As'ad (2012 menyebutkan bahwa penampilan kerja adalah succesful role achievement yang diperoleh seseorang dari perbuatan-perbuatannya. Dengan kata lain, penam- 
pilan kerja sebagai kesuksesan seeorang dapat melaksanakan pekerjaannya. Jadi, penampilan kerja dapat diartikan sebagai hasil hanya dicapai oleh seseorang menurut ukuran yang berlaku untuk pekerjaan adalah tugas yang bersangkutan.

Menurut Indrawijaya (2012), prestasi kerja seseorang bergantung pada keinginannya (motivasi) untuk berprestasi dan kemampuan untuk melakukannya. Ada tiga variabel yang mempengaruhi perilaku dan penampilan kerja yaitu individu, variabel organisasi dan variabel psikologi. Hasil dari perilaku individu di dalam organisasi tampak dalam bentuk penampilan kerja. Sehingga, di dalam organisasi variabel organisasi dan variabel psikologi tidak hanya mempengaruhi prilaku tetapi juga penampilan kerja seseorang. Penampilan kerja adalah prilaku yang berkaitan langsung dengan tugas-tugas pekerjaan dan yang perlu diselesaikan untuk mencapai karakteristik individu ini memerlukan penyesuaian terhadap situasi tempat kerja dan organisasinya dan pada umunya sikap terhadap pekerjaan dapat mempengaruhi kerja atau demikian pula sebaliknya. Jadi, dapat disimpulkan bahwa keterampilan petugas merupakan hasil interaksi antara motivasi dan kemampuan pada diri seseorang. Orang yang tinggi motivasinya, tetapi rendah kemampuannya, akan menghasilkan penampilan kerja yang rendah pula. Begitu pula orang yang kemampuannya, dan motivasinya rendah dan penampilan kerja tinggi diperlukan adanya orang yang memiliki motivasi dan kemampuan tinggi (Indrawijaya, 2012).

Untuk dapat melaksanakan tugas dengan baik sebuah instansi yang memberikan pelayanan kepada masyarakat harus beberapa fungsi, salah satu diantaranya adalah fungsi menyelenggarakan pelayanan dengan melengkapi sarana dan prasarana yang dibutuhkan pada saat bekerja. Secara umum dalam sebuah instansi sarana itu merupakan salah satu bagian dari lingkungan kerja yang akan mempengaruhi mutu pelayanan yang diberikan. Menurut Yandianto (2011) sarana adalah sesuatu yang dipakai sebagai alat dalam mencapai maksud dan tujuan yang diinginkan.

Sarana merupakan aset sebuah organisasi dalam rangka pencapaian tujuan. Dengan adanya sarana yang lengkap, maka pegawai akan mudah untuk melaksanakan tugas dan fungsinya sebagai pemberi pelayanan. Selain itu dengan sarana yang memadai juga akan mempengaruhi profesional kerja pegawai dan mendatangkan kepuasan pada masyarakat yang datang (Sedarmayanti, 2011).

Ketepatan waktu yang dimaksud antara lain meliputi waktu yang dibutuhkan oleh seorang untuk mendapatkan pelayanan yang dimulai dari pendaftaran, pengurusan di bagian administrasi, waktu tunggu dalam proses pelayanan. Pelayanan yang handal mencerminkan ketepatan waktu pelayanan dan kesigapan pegawai dalam meberikan pelayanan. Pelayanan yang handal akan dapat memuaskan pelanggan. Faktor perilaku manusia adalah dapat menentukan, selain bentuk isi (content) mutu barang atau jasa yang diberikan. Perilaku yang baik dalam memberikan pelayanan menurut De Vriye dalam (Nurmiah, 2012) adalah sebagai berikut ini.

1. Self-esteem, yaitu penghargaan terhadap diri sendiri, dengan pandai menghargai dirinya sendiri, seorang karyawan akan berpikiran dan bertindak positif terhadap orang lain, sehingga pandai menghargai pelanggan dengan baik.

2. Exceed expectation, yaitu memberikan pelayanan dengan melebihi harapan pasien (mematuhi dan melebihi standar) secara konsisten.

3. Recovery, yaitu adanya keluhan pasien jangan dianggap sebagai suatu beban masalah, namun dianggap sebagai suatu peluang untuk memperbaiki atau meningkatkan diri.

4. Vision, yaitu pelayanan prima sangat berkaitan dengan visi organisasi yang terkait.

5. Care, yaitu perhatian atau perlakuan terhadap pasien dengan baik dan tulus.

6. Pemberdayaan, yaitu memberdayakan agar karyawan mampu bertanggungjawab.

Manfaat keandalan (reliability) adalah sebagai berikut:

1. diketahui kelemahan atau kekurangan dari masing-masing unsur dalam penyelenggaraan pelayanan publik;

2. diketahui kinerja penyelenggaraan pelayanan yang telah dilaksanakan oleh unit pelayanan publik secara periodik; 
3. sebagai bahan penetapan kebijakan yang perlu diambil dan upaya yang perlu dilakukan;

4. diketahui indeks kepuasan masyarakat secara menyeluruh terhadap hasil pelaksanaan pelayanan publik pada lingkup pemerintah pusat dan daerah;

5. memacu persaingan positif, antar unit penyelenggara pelayanan pada lingkup pemerintah pusat dan daerah dalam upaya peningkatan kinerja pelayanan; dan

6. bagi masyarakat dapat diketahui gambaran tentang kinerja unit pelayanan.

\section{Metode Penelitian}

Menurut Sugiyono, (2012:87) Populasi adalah wilayah generalisasi yang terdiri atas obyek/subyek yang mempunyai kualitas dan karakteristik tertentu yang ditetapkan untuk dipelajari dan kemudian ditarik kesimpulannya. Populasi dalam penelitian ini adalah seluruh masyarakat yang menggunakan jasa pelayanan di KUA Liang Anggang Kota Banjarbaru. Jumlah populasi pada penelitian ini dapat dikatakan tidak terbatas, oleh karena itu diambil jumlah sampel sebanyak rata-rata jumlah masyarakat yang berurusan di Kantor Urusan Agama Liang Anggang Kota Banjarbaru setiap bulannya, yaitu 50 orang. Oleh karena itu, sampel dalam penelitian ini ada 50 responden. Sampel diambil secara accidental terhadap mereka yang membutuhkan pelayanan dari Kantor Urusan Agama Liang Anggang Kota Banjarbaru dalam 1 bulan.

Instrumen yang digunakan untuk mengambil data adalah kuesioner yang membahas tentang tiga hal, yaitu:

Variabel Bebas :

$\mathrm{X} 1$ : Keandalan

X2 : Prosedur Layanan

Variabel Terikat :

Y : Kepuasan Masyarakat

Data yang digunakan adalah data primer. Data yang telah dikumpulan kemudian di tabulasi dan dianalsis dengan menggunakan teknik analisis regresi berganda.

\section{Hasil Penelitian dan Pembahasan}

Rekapitulasi tanggapan responden bertujuan untuk mendeskrifsikan variabel-variabel penelitian melalui interprestasi distribusi frekuensi jawaban responden secara keseluruhan, baik dalam jumlah responden (orang), maupun dalam angka persentase terhadap item-item variabel penelitian Supriyanto dan Machfudz (2011), adapun frekuensi jawaban responden untuk jawaban pertanyaan variabel keandalan $\left(\mathrm{X}_{1}\right)$, prosedur layanan $\left(\mathrm{X}_{2}\right)$ dan kepuasan masyarakat (Y) dapat dilihat pada Tabel 1.

Berdasarkan tabel 1, dari variabel keandalan $\left(\mathrm{X}_{1}\right)$ pada item pertanyaan $\left(\mathrm{X}_{1.1}\right)$ dari 50 masyarakat pada KUA Liang Anggang Kota Banjarbaru jawaban paling dominan adalah sebanyak 24 orang (48\%) menjawab setuju; item pertanyaan $\left(\mathrm{X}_{1.2}\right)$ jawaban paling dominan adalah sebanyak 23 orang (46\%) menjawab setuju, item pertanyaan $\left(\mathrm{X}_{1.3}\right)$ jawaban paling dominan adalah sebanyak 24 orang $(48 \%)$ menjawab setuju; item pertanyaan $\left(\mathrm{X}_{1.4}\right)$ jawaban paling dominan adalah sebanyak 22 orang (44\%) menjawab sangat setuju dan item pertanyaan $\left(\mathrm{X}_{1.5}\right)$ jawaban paling dominan adalah sebanyak 23 orang (46\%) menjawab sangat setuju.

Variabel Prosedur Layanan $\left(\mathrm{X}_{2}\right)$ pada item pertanyaan $\left(\mathrm{X}_{2.1}\right)$ dari 50 masyarakat pada KUA Liang Anggang Kota Banjarbaru jawaban paling dominan adalah sebanyak 19 orang $(38 \%)$ menjawab sangat setuju; item pertanyaan $\left(\mathrm{X}_{2.2}\right)$ jawaban paling dominan adalah sebanyak 19 orang (38\%) menjawab sangat setuju; item pertanyaan $\left(\mathrm{X}_{2.3}\right)$ jawaban paling dominan adalah sebanyak 20 orang (40\%) menjawab sangat setuju; item pertanyaan $\left(\mathrm{X}_{2.4}\right)$ jawaban paling dominan adalah sebanyak 16 orang (32\%) menjawab sangat setuju; item pertanyaan $\left(\mathrm{X}_{2.5}\right)$ jawaban paling dominan adalah sebanyak 22 orang (44\%) menjawab sangat setuju; item pertanyaan $\left(\mathrm{X}_{2.6}\right)$ jawaban paling dominan adalah sebanyak 22 orang (44\%) menjawab sangat setu$\mathrm{ju}$; item pertanyaan $\left(\mathrm{X}_{2.7}\right)$ jawaban paling dominan adalah sebanyak 18 orang (36\%) menjawab sangat setuju dan item pertanyaan $\left(\mathrm{X}_{2.8}\right)$ jawaban paling dominan adalah sebanyak 21 orang (42\%) menjawab setuju. 
Tabel 1. Distribusi Frekuensi Jawaban Responden

\begin{tabular}{|c|c|c|c|c|c|c|c|c|c|c|}
\hline \multirow{3}{*}{ Item } & \multicolumn{10}{|c|}{ Jawaban Responden } \\
\hline & \multicolumn{2}{|c|}{1 (STS) } & \multicolumn{2}{|c|}{$2(\mathrm{TS})$} & \multicolumn{2}{|c|}{$3(\mathrm{~N})$} & \multicolumn{2}{|c|}{$4(S)$} & \multicolumn{2}{|c|}{$5(\mathrm{SS})$} \\
\hline & $\mathrm{F}$ & $\%$ & $\mathrm{~F}$ & $\%$ & $\mathrm{f}$ & $\%$ & $\mathrm{f}$ & $\%$ & $\mathrm{f}$ & $\%$ \\
\hline $\mathrm{X}_{1.1}$ & 7 & 14 & 12 & 24 & 7 & 14 & 24 & 48 & 0 & 0 \\
\hline $\mathrm{X}_{1.2}$ & 6 & 12 & 8 & 12 & 13 & 26 & 23 & 46 & 0 & 0 \\
\hline $\mathrm{X}_{1.3}$ & 6 & 12 & 9 & 18 & 11 & 22 & 24 & 48 & 0 & 0 \\
\hline $\mathrm{X}_{1.4}$ & 6 & 12 & 11 & 22 & 11 & 22 & 22 & 44 & 0 & 0 \\
\hline $\mathrm{X}_{1.5}$ & 4 & 8 & 9 & 18 & 14 & 28 & 23 & 46 & 0 & 0 \\
\hline $\mathrm{X}_{2.1}$ & 3 & 6 & 2 & 4 & 13 & 26 & 13 & 26 & 19 & 38 \\
\hline $\mathrm{X}_{2.2}$ & 2 & 4 & 5 & 10 & 12 & 24 & 12 & 24 & 19 & 38 \\
\hline $\mathrm{X}_{2.3}$ & 2 & 4 & 7 & 14 & 9 & 18 & 12 & 24 & 20 & 40 \\
\hline $\mathrm{X}_{2.4}$ & 1 & 2 & 5 & 10 & 14 & 28 & 16 & 32 & 14 & 28 \\
\hline $\mathrm{X}_{2.5}$ & 2 & 4 & 4 & 8 & 13 & 26 & 9 & 18 & 22 & 44 \\
\hline $\mathrm{X}_{2.6}$ & 1 & 2 & 6 & 12 & 11 & 22 & 10 & 20 & 22 & 44 \\
\hline $\mathrm{X}_{2.7}$ & 2 & 4 & 4 & 8 & 10 & 20 & 16 & 32 & 18 & 36 \\
\hline $\mathrm{X}_{2.8}$ & 3 & 6 & 3 & 6 & 9 & 18 & 21 & 42 & 14 & 28 \\
\hline $\mathrm{Y}_{1}$ & 2 & 4 & 7 & 14 & 11 & 22 & 14 & 28 & 16 & 32 \\
\hline $\mathrm{Y}_{.2}$ & 0 & 0 & 8 & 16 & 8 & 16 & 16 & 32 & 18 & 36 \\
\hline $\mathrm{Y} .3$ & 0 & 0 & 6 & 12 & 5 & 10 & 24 & 48 & 15 & 30 \\
\hline $\mathrm{Y}_{.4}$ & 1 & 2 & 7 & 14 & 11 & 22 & 23 & 46 & 8 & 16 \\
\hline $\mathrm{Y} .5$ & 0 & 0 & 7 & 14 & 8 & 16 & 22 & 44 & 13 & 26 \\
\hline$Y_{.6}$ & 3 & 6 & 6 & 12 & 4 & 8 & 27 & 54 & 10 & 20 \\
\hline $\mathrm{Y} .7$ & 1 & 2 & 6 & 12 & 21 & 42 & 18 & 36 & 4 & 8 \\
\hline $\mathrm{Y}_{.8}$ & 3 & 6 & 3 & 6 & 10 & 20 & 18 & 36 & 16 & 32 \\
\hline Y.9 & 1 & 2 & 3 & 6 & 10 & 20 & 19 & 38 & 17 & 34 \\
\hline $\mathrm{Y}_{10}$ & 0 & 0 & 6 & 12 & 9 & 18 & 22 & 44 & 13 & 26 \\
\hline $\mathrm{Y}_{11}$ & 3 & 6 & 8 & 16 & 8 & 16 & 16 & 32 & 15 & 30 \\
\hline $\mathrm{Y}_{.12}$ & 3 & 6 & 6 & 12 & 13 & 26 & 11 & 22 & 17 & 34 \\
\hline $\mathrm{Y}_{.13}$ & 1 & 2 & 6 & 12 & 12 & 24 & 16 & 32 & 15 & 30 \\
\hline $\mathrm{Y}_{.14}$ & 2 & 4 & 1 & 2 & 9 & 18 & 13 & 26 & 25 & 50 \\
\hline
\end{tabular}

Dari variabel kepuasan masyarakat $(\mathrm{Y})$ pada item pertanyaan $\left(\mathrm{Y}_{1}\right)$ dari 50 masyarakat pada KUA Liang Anggang Kota Banjarbaru jawaban paling dominan adalah sebanyak 16 orang (32\%) sangat setuju; item pertanyaan $\left(\mathrm{Y}_{2}\right)$ jawaban paling dominan adalah sebanyak 18 orang (36\%) menjawab setuju; item pertanyaan $\left(\mathrm{Y}_{3}\right)$ jawaban paling dominan adalah sebanyak 24 orang $(48 \%)$ menjawab setuju; item pertanyaan $\left(\mathrm{Y}_{4}\right)$ jawaban paling dominan adalah sebanyak 23 orang (46\%) menjawab setuju; item pertanyaan $\left(\mathrm{Y}_{5}\right)$ jawaban paling dominan adalah sebanyak 23 orang $(46 \%)$ menjawab sangat setuju; item pertanyaan $\left(\mathrm{Y}_{6}\right)$ jawaban paling dominan adalah sebanyak 27 orang (54\%) menjawab setuju; item pertanyaan $\left(\mathrm{Y}_{7}\right)$ jawaban paling dominan adalah sebanyak 21 orang (42\%) menjawab netral; item pertanyaan $\left(\mathrm{Y}_{8}\right)$ jawaban paling dominan adalah sebanyak 18 orang (36\%) menjawab setuju; item pertanyaan $\left(\mathrm{Y}_{9}\right)$ jawaban paling dominan adalah sebanyak 19 orang (38\%) menjawab setuju; item pertanyaan $\left(\mathrm{Y}_{10}\right)$ jawaban paling dominan adalah sebanyak 22 orang $(44 \%)$ menjawab setuju; item pertanyaan $\left(\mathrm{Y}_{.11}\right)$ jawaban paling dominan adalah sebanyak 16 orang (32\%) menjawab setuju, item pertanyaan $\left(\mathrm{Y}_{12}\right)$ jawaban paling dominan adalah sebanyak 17 orang (34\%) menjawab sangat setuju; item pertanyaan $\left(\mathrm{Y}_{13}\right)$ jawaban paling dominan adalah sebanyak 16 orang (32\%) menjawab setuju; item pertanyaan $\left(\mathrm{Y}_{14}\right)$ ja- 
waban paling dominan adalah sebanyak 25 orang (50\%) menjawab sangat setuju.

Melalui pengujian ini akan dapat diketahui apakah variabel yang terdiri dari keandalan $\left(\mathrm{X}_{1}\right)$, prosedur layanan $\left(\mathrm{X}_{2}\right)$ berpengaruh secara parsial terhadap kepuasan masyarakat (Y) pada Kementerian Agama Kota Banjarbaru, yaitu dengan cara yaitu dengan cara membandingkan nilai probabilitas signifikansi variabel dengan probabilitas sebesar $5 \%(\alpha=0,05)$ apabila nilai probabilitas signifikansi $<(\alpha=0,05)$ maka terdapat pengaruh signifikan terhadap variabel terikatnya, begitu juga sebaliknya, dan df $=\mathrm{n}-\mathrm{K}-1=50-$ $3-1=46$ maka didapat nilai $\mathrm{t}$ tabel 2,013 adapun hasil perhitungan statistik dapat di lihat pada tabel 2 dibawah ini :

Tabel 2. Nilai $\boldsymbol{t}_{\text {hitung }}$

\begin{tabular}{ccccc}
\hline Variabel & $\mathrm{t}_{\text {hitung }}$ & $\mathrm{t}_{\text {tabel }}$ & Sig. & Signifikansi \\
\hline $\mathrm{X}_{1}$ & 7,659 & 2,013 & 0,000 & Signifikan \\
\hline $\mathrm{X}_{2}$ & 4,013 & 2,013 & 0,000 & Signifikan \\
\hline
\end{tabular}

Berdasarkan Tabel 2, dapat dilihat pengaruh variabel keandalan $\left(\mathrm{X}_{1}\right)$ terhadap kepuasan masyarakat (Y). Nilai probabilitas signifikansi yaitu $0,000<0,05$ dan $t_{\text {hitung }}$ $7,659>t_{\text {tabel }} 2,013$, sehingga dapat disimpulkan bahwa keandalan $\left(\mathrm{X}_{1}\right)$ berpengaruh signifikan secara parsial terhadap kepuasan masyarakat (Y) pada KUA Liang Anggang Kota Banjarbaru .

Pengaruh variabel prosedur layanan $\left(\mathrm{X}_{2}\right)$ terhadap kepuasan masyarakat $(\mathrm{Y})$, prosedur layanan $\left(\mathrm{X}_{2}\right)$ berpengaruh signifikan secara parsial terhadap kepuasan masyarakat (Y). Nilai probabilitas signifikansi yaitu $0,000<0,05$ dan $\mathrm{t}_{\text {hitung }} 4,013>2,013$, sehingga dapat disimpulkan bahwa parsial prosedur layanan $\left(\mathrm{X}_{2}\right)$ berpengaruh siginifikan secara sendiri sendiri atau parsial terhadap kepuasan masyarakat (Y) pada KUA Liang Anggang Kota Banjarbaru.

Uji $F$ digunakan dengan tujuan untuk membuktikan apakah variabel bebas berpengaruh secara bersama-sama terhadap variabel terikat. Dari hasil perhitungan melalui SPSS menunjukan $F_{\text {hitung }}$ sebesar 25,065 dan $\mathrm{F}_{\text {tabel }}$ di dapat dengan df $1=\mathrm{K}-1=3-1=2$ dan df $2=\mathrm{n}-\mathrm{K}=50-3=47$ maka nilai $F_{\text {tabel }}$ sebesar 3,200 dan apabila signifikansi < 0,05 maka dapat disimpulkan variabel bebas berpengaruh signifikan terhadap variabel terikatnya. Berdasarkan teori tersebut maka nila

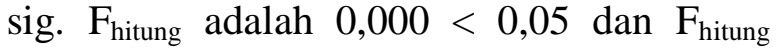
45,353>3,200, sehingga hipotesis kedua yang mengatakan keandalan dan prosedur layanan berpengaruh signifikan secara simultan terhadap kepuasan masyarakat pada KUA Liang Anggang Kota Banjarbaru dapat diterima atau teruji

Pada hipotesis ketiga yang menyatakan bahwa keandalan $\left(\mathrm{X}_{1}\right)$ merupakan faktor yang dominan berpengaruh terhadap kepuasan masyarakat (Y) adalah benar atau terbukti, karena hasil penelitian menunjukkan variabel yang berpengaruh dominan terhadap kepuasan masyarakat masyarakat pada KUA Liang Anggang Kota Banjarbaru adalah keandalan $\left(\mathrm{X}_{1}\right)$, karena memiliki nilai beta (beta coefficient) paling besar dari pada variabel bebas lainnya yaitu $\mathrm{X}_{1} 0,666>\mathrm{X}_{2} 0,349$

\section{Kesimpulan}

Berdasarkan hasil penelitian, dapat ditarik kesimpulan sebagai berikut ini.

1. Variabel keandalan dan prosedur layanan berpengaruh secara parsial terhadap kepuasan masyarakat pada KUA Liang Anggang Kota Banjarbaru.

2. Keandalan dan prosedur layanan berpengaruh secara simultan terhadap kepuasan masyarakat pada KUA Liang Anggang Kota Banjarbaru.

3. Keandalan merupakan variabel yang dominan pengaruhnya terhadap kepuasan masyarakat pada KUA Liang Anggang Kota Banjarbaru.

\section{DAFTAR PUSTAKA}

Abidin Zainal, 2010, "Analisis Pengaruh Keandalan dan Etos Kerja terhadap Pelayanan Publik Pegawai Kantor Pelayanan Pajak Pratama Medan Kota“, Universitas Sumatera Utara, Medan.

Ariani Wahyuni, 2012, Manajemen Operasional Jasa, Graha Ilmu, Yogyakarta.

As'ad Moh., 2012, Psikologi Industri, Liberty, Yogyakarta.

Dutka Alan, 2008, AMA Handbook for Customer Satisfaction, NTC Business Book, Lincolnwood, Illinois. 
Hoffman, John dan Douglas Beteson, 2012, Services Marketing: Concepts,. Strategies, and Cases, Third Edition, Thomson South-Western, USA

Pohan Imbalo S., 2012. Jaminan Mutu Layanan Kesehatan, EGC, Jakarta.

Indrawijaya, 2012, Perilaku Organisasi, Sinar Baru, Jakarta.

Julita, 2011, "Pengaruh Kualitas Pelayanan terhadap Kepuasan Mahasiswa Fakultas Ekonomi Universitas Sumatera Utara", Skripsi, Universitas Sumatera Utara, Medan.

Kamaruddin Ahmad, 2011, Akuntansi Manajemen: Dasar-dasar Konsep Biaya dan Pengambilan Keputusan, Raja Grafindo, Jakarta.

Kotler Philip, .2011, Manajemen Pemasaran, Edisi Millenium, Prenhallinda, Jakarta.

Lupiyoadi Hamdani, 2011, Manajemen Pemasaran Jasa, Edisi Kedua, Salemba Empat, Jakarta.

Lupiyoadi Rambat, 2012, Manajemen Pemasaran Jasa, Salemba Empat, Jakarta.

Mahmudi, 2012, Manajemen Kinerja Sektor Publik, UPP AMP YKPN, Yogyakarta.

Masya Ismail, 2011, Manajemen, Effhar Offset, Semarang.

Moekijat, 2011, Pengantar SIM, Remaja Rosdakarya, Bandung.

Mowen, John C., 2011, Consumer Behavior, $4^{\text {th }}$ Edition, Prentice Hall International Inc., London.

Nurmiah, 2012, Pelayanan yang Optimal. Gramedia Pustaka Utama, Jakarta.

Ratminto dan Atik, 2011, Manajemen Pelayanan, Pustaka Pelajar, Jakarta.

Republik Indonesia, Keputusan Menteri
Pemberdayaan Aparatur Negara Nomor: 63/KEP/M.PAN/7/2003 tentang Pedoman Umum Penyelenggaraan Pelayanan Publik.

Republik Indonesia, Keputusan Menteri Pendayagunaan Aparatur Negara Nomor 26 Tahun 2004 Tentang Petunjuk Teknis Transparansi dan Akuntabilitas dalam Penyelenggaraan Pelayanan $\mathrm{Pu}-$ blik.

Sedarmayanti, 2011, Sumber Daya Manusia dan Produktivitas Kerja, Mandar Maju, Bandung.

Siagian Sondang P., Organisasi dan Perilaku Administrasi, Gunung Agung, Jakarta.

Simamora Bilson, 2012, Panduan Riset Perilaku Konsumen, Gramedia Pustaka Utama, Jakarta.

Sugiyono, 2012, Metode Penelitian Kuantitatif Kualitatif dan $R \& D$, Alfabeta, Bandung.

Supriyanto Achmad Sani dan Machfudz, Mashuri, 2011, Metodologi Riset Manajemen Sumber Daya Manusia, UIN Maliki Press, Malang.

Umar Husein, 2011, Riset Pemasaran dan Perilaku Konsumen, Gramedia Pustaka Utama, Jakarta.

Wyckoff Daryl D., 1978, Management of. Service Operation: Texts and Cases, Boston.

Widjaja Amin, 2011, Manajemen Strategik, Edisi Pertama, Harvarindo, Jakarta.

Yandianto, 2011, Kamus Umum Bahasa Indonesia, M2S, Bandung.

Zahruli, 2012, Pendekatan Mutu dan Kepuasan dalam Pelayanan Kesehatan, Gunung Agung, Jakarta. 